\title{
THREATENED BIODIVERSITY OF SUNDARBAN BIOSPHERE RESERVE WITH REFERENCE TO FAUNAL HABITAT AND NEED FOR ITS PRESERVATION.
}

\author{
Rajeshwari Chatteriee*
}

\begin{abstract}
The beautiful forests of Sundarbans embracing a mysterious tract of wilderness are located in the lower Ganga delta of Bengal. The mangrove forests and the overall ecosystem in Sundarbans are the ideal habitats for large group of ferrestrial, avian and aquatic fauna, starting from Protozoa to Mammals. It contains the richest biodiversity among the inter-fidal forest in the world and is the only natural mangrove forest in the world, where the tiger (Panthera tigris tigris L.) resides. The reason for high faunal diversity is the fact that here the ocean and land come in contact of each other. The succession from ocean to land and to fresh water/ brackish-water through estuaries, change in water salinity from almost nil to high through grades of different concentration; newly formed islands with soft swampy mud to mature old islands with hard saline banks provides fascinoting habitat opportunities to various organism. During the last two centuries, these highly productive mangrove ecosystems had been suffering from rapid destruction and degradation. If this negligence or ignorance continues in future there
\end{abstract}

* HMCT Department, B.I.T, Mesra, Ranchi. 
will be random exploitation of this notural resource and loss of diverse biota will be unavoidable. A genuine understanding of the interaction of responsible factors should be of paramount interest to the estuarine ecosystem and for prosperity. Recently, it has been established that natural factors along with direct and indirect human inferferences have largely changed the biological composition, ecosystem function, productivity, and regeneration and succession patterns within the mangrove ecosystem.

Keywords: Biodiversity, Threats, Sundarbans, Faunal Habitat, Preservation.

\section{Introduction}

The Sundarban, covering about one million ha in the delta of the rivers Ganga, Brahmaputra and Meghna is shared between Bangladesh ( $-60 \%)$ and India $(\sim 40$ $\%$ ), and is the world's largest coastal wetland. It is a land of majestic beauty for its tropical humid forest, luxuriant mangroves, wide rivers, sea facing islands and extensive estuaries. It lies between $27^{\circ} 0^{\prime}-27^{\circ} 27^{\prime} \mathrm{N}$ and $88^{\circ} \mathrm{O}^{\prime}-89^{\circ} \mathrm{O}^{\prime} \mathrm{E}$ covering an area of $9,630 \mathrm{sq} . \mathrm{km}$, out of which 4,096 sq. km. is under Indian administration. The area experiences a subtropical monsoonal climate with an annual rainfall of $1,600-1,800 \mathrm{~mm}$ and severe cyclonic storms. Enormous amounts of sediments carried by the rivers contribute to its expansion and dynamics. Salinity gradients change over a wide range of spatial and temporal scales. The biodiversity includes about 350 species of vascular plants, 250 fishes and 300 birds, besides numerous species of phytoplankton, fungi, bacteria, zooplankton, benthic invertebrates, molluscs, reptiles, amphibians and mammals. Species composition and community structure vary east to west, and along the hydrological and salinity gradients. Sundarban is the habitat of many rare and endangered animals (Batagur baska, Pelochelys bibroni, Chelonia mydas), especially the Royal Bengal tiger (Panthera tigris). Javan rhino, wild buffalo, hog deer, and barking deer are now extinct from the area. Large areas of the Sundarban mangroves have been converted into paddy fields over the past two centuries, and more recently into shrimp farms. The Sundarban has been extensively exploited for timber, fish, prowns and fodder. The regulation of river flows by a series of dams, barrages and embankments for diverting water upstream for various human needs and for flood control has caused large reduction in freshwater inflow and seriously affected the biodiversity because of an increase in salinity and changes in sedimentation. Heritiera fomes (locally called Sundari, from which Sundarban derives its name), Nypa fruticans and Phoenix paludosa are declining rapidly. During the past three decades, large parts of the remaining Sundarban have been protected for wildlife, particularly tiger, through the creation of several sanctuaries and a biosphere resenve. 
The major land use patterns of the mangrove regions involve areas meant for agriculture, wildlife, forestry and recreation. The people have reclaimed the mangrove areas of the Sundarbans for many years for their settlement and agriculture. Most of the mangrove areas in the Indian Sundarbans have been degraded and converted to busy areas for the construction of harbours, industries, agricultural fields, human habitation, grazing grounds or for regular exploitation of the forest products and also for the enhancement of eco-tourism.

Oil exploration in coastal areas is also emerging as a new threat. Further threats arise from global climate change, especially sea level rise. The future of the Sundarban will depend upon the management of freshwater resources as much as on the conservation of its biological resources.

Government of India constituted Sundarban Boosphere Reserve (SBR) in 1989 and it received the recognition of UNESCO under its Man and Biosphere (MAB) Programme in November 2001. Sundarban National Park, forming the core area of Sundarban Tiger Reserve, received recognition as World Heritage Site by UNESCO in 1987. It has been nominated by Government of India for recognition as Ramsar Site (a wetland of international importance). Sundarban Tiger Reserve was constituted by Government of India under Project Tiger scheme, in 1973. Sundarban is the only mangrove forest in the world, which is the home of Tiger. Sundarban Tiger Reserve has the highest tiger population in the world.

\section{Methodology}

The present study was undertaken at Indian Sundarbans area of West Bengal which extends from $88^{\circ} 10^{\prime} \mathrm{E}$ to $89^{\circ} 51^{\prime} \mathrm{E}$ longitude and $21^{\circ} 31^{\prime} \mathrm{N}$ to $22^{\circ} 30^{\prime} \mathrm{N}$ latitude. The required data were collected during the course of such field trips, analyzed and presented in the following paper.

\section{Uniqueness of Indian Sundarbans Biosphere Reserve}

In terms of zoogeography the situation of Sundarbans is better than that of any other regions of India. The strategic advantages are due to its unique physical factors, which no other districts in the sub-continent (except the adjoining delta regions of Bangladesh) enjoy. Three great biocycles of ocean, freshwater and land come into contact around the margins of this largest delta of the world. The succession from ocean to land and to the freshwater through estuaries is the most outstanding field for the huge amount of biodiversity. The gradient from saltwater to 
brackish-water to entirely freshwater fluctuates back and forth with the tides. Since freshwater is less dense and warmer, it flows over the top of the saltwater, with the result that strata with different physical characteristics are formed, which are inhabited by different kinds of fauna.

The various species thriving in this vibrating ecosystem exhibit high degree of adaptive modifications as protection against the fluctuating environmental conditions. Topography of Sundarbans is also useful for all kinds of animals. Muddy and sticky substratum is the adobe of many groups of animals whereas deep, dense, mangrove forest is useful for the others who could also very well choose alternative suitable habitat. Burrowing animals easily withstand the cyclone, tidal inundation, weather hazards, etc. by simply retreating themselves completely within the holes. The diversity of animal life in Sundarbans is very vast, which cannot be restricted to their distribution.

The animal fauna can be subdivided on their range of salinity tolerance, which is a deciding factor for the zone closely associared with its mangrove forest, its salinity, its muddy and subsoil chemistry, tidal fluctuation, temperature and humidity. So due to the full adaptation of all the animals with the surrounding environment of Sundarbans, this region contains the richest biodiversity among the inter-tidal forest in the world.

\section{Existing Status of Faunal Diversity in Indian Part of Sundarbans}

The mangrove ecosystem sustains a wide range of faunal diversity. Although, the faunal exploration of Sundarbans can be traced back to mid-eighteenth century and extensive studies have been carried out by the workers of Zoological Survey of India (Annandale, 1907; Kemp, 1917; and Hora, 1934), but the recent works of Nandi et al (1993) and Das \& Nandi (1999) provide an excellent data base of faunal diversity of the ecosystem from Protozoa to Mammals. (Table I). 
Table l: Distribution of animals in relation to habitats in Indian Sundarbans

\begin{tabular}{|c|c|c|c|c|c|c|c|}
\hline \multicolumn{8}{|c|}{ INVERTEBRATE FAUNA (989 species) } \\
\hline \multirow{2}{*}{$\begin{array}{l}\text { King } \\
\text { dom }\end{array}$} & \multirow{2}{*}{$\begin{array}{l}\text { Sub } \\
\text { king } \\
\text { dom }\end{array}$} & \multirow{2}{*}{ Phylum } & \multirow{2}{*}{ Class } & \multirow{2}{*}{$\begin{array}{l}\text { Total } \\
\text { No.of } \\
\text { species }\end{array}$} & \multicolumn{3}{|c|}{$\begin{array}{c}\text { Number of species in representing } \\
\text { zone }\end{array}$} \\
\hline & & & & & \begin{tabular}{|l} 
Supra \\
littoral
\end{tabular} & $\begin{array}{l}\text { Inter } \\
\text { tidal }\end{array}$ & Estuarine \\
\hline \multirow{4}{*}{$\begin{array}{c}\text { PROTI } \\
\text { STA }\end{array}$} & \multirow{4}{*}{$\begin{array}{l}\text { Proto } \\
\text { zoa }\end{array}$} & $\begin{array}{l}\text { Sarcomasti- } \\
\text { gophora }\end{array}$ & & 46 & 26 & 6 & 14 \\
\hline & & Apicomplexa & & 24 & 19 & 1 & 4 \\
\hline & & Myxozoo & & 4 & - & 3 & 1 \\
\hline & & Ciliophora & & 31 & 2 & 19 & 10 \\
\hline \multirow{31}{*}{$\begin{array}{c}\text { ANIMA } \\
\text { LIA }\end{array}$} & & Porifera & & 1 & . & 1 & - \\
\hline & & \multirow{3}{*}{ Cnidaria } & & 33 & 20 & 13 & - \\
\hline & & & Hydrozoa & 13 & - & 13 & - \\
\hline & & & Anthozod & 20 & . & - & 20 \\
\hline & & \multirow{6}{*}{$\begin{array}{l}\text { Clenophora } \\
\text { Platyhel } \\
\text { minthes }\end{array}$} & & 2 & - & - & 2 \\
\hline & & & & 41 & - & 3 & 38 \\
\hline & & & Turbellaria & 1 & & 1 & - \\
\hline & & & Monogenea & 21 & - & 2 & 19 \\
\hline & & & Trematoda & 13 & $\therefore$ & - & 13 \\
\hline & & & Cestoda & 6 & - & - & 6 \\
\hline & & Nemathelminthes & & 68 & - & 68 & - \\
\hline & & Acanthocephala & & 3 & - & - & 3 \\
\hline & & Nemertinea & & 2 & - & 2 & - \\
\hline & & Rotifero & & 4 & - & - & 4 \\
\hline & & Mollusca & & 142 & 12 & 116 & 14 \\
\hline & & Sipuncula & & 2 & - & 2 & - \\
\hline & & Echiura & & 3 & $\cdot$ & 3 & $\because$ \\
\hline & & \multirow{4}{*}{ Annelida } & & 78 & 9 & 69 & - \\
\hline & & & Polychaeta & 69 & - & 69 & - \\
\hline & & & Oligochaetd & 6 & 6 & - & . \\
\hline & & & Hirudinea & 3 & 3 & - & - \\
\hline & & \multirow{5}{*}{ Arthropoda } & & 476 & 234 & 90 & 752 \\
\hline & & & Crustacea & 240 & - & 90 & 150 \\
\hline & & & Insecta & 201 & 201 & - & - \\
\hline & & & Arachnida & 33 & 33 & - & - \\
\hline & & & Merostomatc & 2 & - & - & 2 \\
\hline & & Entoprocta & & 1 & - & - & 1 \\
\hline & & Bryozoa & & 3 & - & $\cdot$ & 3 \\
\hline & & Brchiopoda & & 1 & - & 1 & - \\
\hline & & Chaetognatha & & 4 & - & - & 4 \\
\hline & & Echinodermata & & 20 & - & 74 & 6 \\
\hline
\end{tabular}

Source: Mukheriee (1975); Mandal and Nandi (1969); Nandi et al, (1993); Chaudhuri and Choudhury (1994); Anon (1995). 


\begin{tabular}{|c|c|c|}
\hline \multicolumn{3}{|c|}{ VERTEBRATE FAUNA (445 species) } \\
\hline Phylum & Class & Total No. of species \\
\hline \multirow{5}{*}{ CHORDATA } & Condricthyes & 22 \\
\cline { 2 - 3 } & Osteichthyes & 154 \\
\cline { 2 - 3 } & Amphibia & 8 \\
\cline { 2 - 3 } & Reptilia & 58 \\
\cline { 2 - 3 } & Aves & 163 \\
\cline { 2 - 3 } & Mammatia & 40 \\
\hline
\end{tabular}

Source: Mukheriee (1975); Mandal and Nandi (1969); Nandi et al, (1993); Anon (1995) and Anonymous (1995).

Sundarbans ecosystem is still one of the most biologically productive and taxonomically diverse ecosystems of the indian sub-continent, but about 6 vertebrates have wiped out from this ecosystem, which were once common in this area (Table II) and about 20 species are in the endangered / threatened species list. (Table III)

Table II: Extinct Species from Indian Sundarbans Mangals

\begin{tabular}{|c|c|}
\hline Scientific Name & Common Name \\
\hline Cairina scutulata & White-winged wood duck \\
\hline Muntiacus muntjac & Barking deer \\
\hline Cervus derucbea & Swamp deer \\
\hline Bulbalis bulbalis & Wild buffalo \\
\hline Rhinoceros sondaicus & Javan rhinoceros \\
\hline Rhinoceros unicornes & Great one-horned rhinoceros \\
\hline
\end{tabular}

Source: Das and Nandy, 1999 
Table III: Endangered/Threatened Species of Indian Sundarbans Mangrove Ecosystem

\begin{tabular}{|c|c|}
\hline Scientific Name & Common Name \\
\hline \multicolumn{2}{|c|}{ MAMMALS } \\
\hline Felis viverrina & Fishing cat \\
\hline Panthera tigris tigrisr & Tiger \\
\hline Platanista gangefica & Gangetic dolphin \\
\hline Orcella brevirostris & Irrawady dolphin \\
\hline Neophocaena phocaenoides & Little porpoise \\
\hline \multicolumn{2}{|c|}{ BIRDS } \\
\hline Ardea goliath & Giant heron \\
\hline Leptoptilos dubius & Adjutant stork \\
\hline Haliacetus leucogastar & White bellied sea eagle \\
\hline Pandion haliaefus & Osprey \\
\hline \multicolumn{2}{|c|}{ Reptiles } \\
\hline Crocodilus porosus & Estuarine Crocodile \\
\hline Lepidochalys olivacea & Olive Ridley turtle \\
\hline Batagur baska & Batagur turtle \\
\hline Kachuga teefa & Indian tent turtle \\
\hline Lissemys punctato & Indian flap shelled turtle \\
\hline Troonyx gangeticus & Indian soft shelled turtle \\
\hline Troonyx hurun & Peacock marked soft shelled turtle \\
\hline Voranus bengalensis & Common Indian monitor \\
\hline Varanus flavesceus & Yellow monitor \\
\hline Varanus salvator & Water monitor \\
\hline Python molurus & Indian rolled python \\
\hline
\end{tabular}

Source: Mangroves of the Sundarbans, Volume I: India, by A. B. Chaudhury and A. Choudhury, IUCN, 1994. 


\section{Status of Different Faunal Habitats in Indian Sundarbans}

\begin{tabular}{|c|c|c|}
\hline Different Faunal Habitat & $\begin{array}{c}\text { Dominant Animal } \\
\text { Species }\end{array}$ & Existing Habitats \\
\hline Estuarine and River Water & $\begin{array}{l}\text { Crocodile, Dolphin. Water } \\
\text { monitor, Shell-fish, Fin-fish, } \\
\text { Tortoise, Turtle, Terrapins, } \\
\text { numbers of Aquatic Fauna }\end{array}$ & $\begin{array}{l}\text { Dolphin and some of the } \\
\text { shellfish and finfish species } \\
\text { are becoming rare and } \\
\text { threatened. }\end{array}$ \\
\hline $\begin{array}{c}\text { Naked River Flats / River } \\
\text { Slopes }\end{array}$ & $\begin{array}{l}\text { Different species of } \\
\text { Molluscs, Crabs, Annelids } \\
\text { and Insects. }\end{array}$ & $\begin{array}{l}\text { Status of different species is } \\
\text { not explored in Sundarbans. }\end{array}$ \\
\hline $\begin{array}{l}\text { Vegetated River Flats and } \\
\text { River Slopes }\end{array}$ & $\begin{array}{l}\text { Spotted Deer, Monkey, Wild } \\
\text { Boar, Snakes, Frogs, } \\
\text { Insects, Annelids, } \\
\text { Molluscs, Crustaceans. }\end{array}$ & $\begin{array}{l}\text { Status of micro and smaller } \\
\text { animals are not assessed } \\
\text { in India Sundarbans, but } \\
\text { population decreasing. }\end{array}$ \\
\hline Different Faunal Habitat & $\begin{array}{c}\text { Dominant Animal } \\
\text { Species }\end{array}$ & Existing Habitats \\
\hline $\begin{array}{l}\text { Dense Mangrove } \\
\text { Forest Floor }\end{array}$ & $\begin{array}{l}\text { Tiger, Fishing Cat, Leopard } \\
\text { Cat, Jackal, Fox, Toddy Cat, } \\
\text { Civet, Wild Boar, Spotted } \\
\text { Deer and few others }\end{array}$ & $\begin{array}{l}\text { Tiger population is said to } \\
\text { be increasing after } \\
\text { conservation measure by } \\
\text { Sundarban Tiger Reserve. }\end{array}$ \\
\hline $\begin{array}{l}\text { Naked Mangrove Forest } \\
\text { Floor }\end{array}$ & $\begin{array}{l}\text { Snakes, Frogs, Rodents, } \\
\text { Lesser Cat, Molluscs, } \\
\text { Crustaceans, Insects, } \\
\text { Annelids, etc. }\end{array}$ & $\begin{array}{l}\text { Status of different species } \\
\text { are not explored in } \\
\text { Sundarbans. }\end{array}$ \\
\hline Tree Canopy & $\begin{array}{l}\text { Monkey, Bat, Birds, Snakes, } \\
\text { Insects, Molluscs and } \\
\text { others. }\end{array}$ & $\begin{array}{l}\text { Migratory and other birds } \\
\text { species gradually } \\
\text { decreasing. }\end{array}$ \\
\hline Amphibian Habitat & $\begin{array}{l}\text { Most macro fauna, i.e., } \\
\text { Tiger, Crocodile, Snakes, } \\
\text { water monitor, good } \\
\text { number of other fauna. }\end{array}$ & $\begin{array}{l}\text { Heavy pressure threatened } \\
\text { most of these fauna and } \\
\text { their habitats in Indian } \\
\text { Sundarbans. }\end{array}$ \\
\hline
\end{tabular}

\section{Glimpse of Faunal Resources in Indian Sundarbans}

Sundarbans environment supports excellent wildlife resources in the mangrove swamps and is a host to important economic species in its aquatic ecosystem. The faunal resources can be utilized for industrial development and exports. Scientific utilization of these faunal resources through fishery, froggery and faunal farming 
may provide a base for employment and ancillary industries. This will help in the upliftment of the rural economy in addition to agri-maricultural prosperity of the country.

\section{- Invertebrate Faunal Resources}

Invertebrates are important faunal components of the Indian Sundarbans. In the mangrove ecosystem of deltaic Sundarbans, almost all the major invertebrate phyla are found with considerable species richness and a good number of them are commercially important.

There are well over 300 species of marine and freshwater fishes, prawns and crabs occurring in this region. Among these, the most highly valued economic species is the Tiger prawn (Penaeus monodon). In fact, major economic activities this region centre round this species through collecting and marketing seeds as well as rearing and farming in brackish water bheries. Amongst fin fishes, the highly priced hilsa (Tevalosa ilisha), bhetki (Lates calcarifer), bhangone (Liza tade), parse (Liza parsia), etc., form a lucrative fishery of this region. The economically important species of animals which mainly comprise of fishes, crustaceans and molluscs prawns are iced and transported to the Calcutta markets. A major portion of the landings is usually exported as dry and frozen products to neighbouring countries. Major markets for frozen shrimp from India are in Japan, West Europe and USA, while the mud crab, Scylla serrata is exported alive to countries like Singapore, Thailand, Malaysia, Japan and Hong-Kong. The export of live mud crab alone from this region was recorded as 518 tonnes valued at Rs.3.83 crores in 1995-96. (Source: Regional Office MPEDA). This indicates the export earning potentials of this region.

i. The rock bees (Apis dorsata), a conspicuous insect fauna of Sundarbans are intimately associated with the socio-economy of Sundarbans. A large number of honey collectors are engaged in this trade.

ii. The crustacean prawns and crabs are the chief dominating fauna. Depending on the varieties of edible prawns and shrimps and crabs, prawn culture, shrimp culture and crab culture have been developed in this region, which help in rural economy.

iii. The mangrove wetland of Indian Sundarbans also forms the habitat of two species of horseshoe crabs in this ecosystem namely Carcinoscorpius rotundicauda and Tachypleus gigas. They have excellent biomedical values and have recently been established as potential source of biotic substances, like Carcinoscorpius Amoebocyte Lysate (CAL) and Tachypleus Amoebocyte Lysate (TAL). 
iv. Among molluscs, various gastropod and bivalve shells can be utilize in the lime industry. Many are edible and may profitably be involved in the shell fishery.

v. The benthic invertebrate community encompasses several untapped marine living resources like edible oysters (Saccostrea cucullata and Crassostrea cuttackensis), calms, mussels, etc., which can bring important commercial culture to provide alternative source of livelihood.

vi. Innumerable planktons and protozoans contribute themselves as food for fishes and other aquatic animals.

\section{Vertebrate Faunal Resources}

The Sundarbans mangrove ecosystem is also a unique resenoir of vertebrate fauna. This ecosystem is rich in terrestrial, aquatic and avian faunal community. Many of these well-represented vertebrates in the Sundarbans are endangered in other parts of the world and have maintained a unique status as a Heritage Site.

i. Variety of commercially important fish species has been recorded in coastal areas of Sundarbans, which is a main source of income of Sundarbans rural people. Non-edible and other low rated fishes are used for making fish-meal, poultry feed and manures.

ii. The creeks of Sundarbans form the home of estuarine crocodile (Crocodylus porosus). It is the nesting ground of Olive Ridley turtle (Lepidochelys olivacea) and River Terrapin (Batagur baska). The largest lizard of the world - Water Monitor (Varanus salvator) and Monitor Lizard (Varanus flavescens) are common in marshy places. Different species of poisonous and non-poisonous snakes are seen in abundance in this region.

iii. Unlimited varieties of crops for food and mangrove forest and trees for shelter provide most lucrative natural abode for many species of birds. Sundarbans also attracts large number of the migratory birds, which enjoy roosting in this place.

iv. The mangrove forest of Sundarbans is the excellent habitat for the largest tiger population in the globe. Apart from Bengal Tiger, this forest has different types of wild mammals, like, Spotted Deer, Wild Pig, Fishing Cat, Civet Cat, Mongoose, Jackal, Fox, Monkey are found in plenty. The Fruit Bats and Flying Foxes are common in the garden. The Bandicot rats, House rats and Shrews are frequently met with in the huts and houses. Among aquatic mammals Irrawaddy Dolphins and Porpoises are common in the estuarine rivers. 


\section{Major Threats to Indian Sundarbans Biodiversity}

The deltaic Sundarbans has been facing various kinds of threats. These threats are offen direct functions of the people's need for the natural resources, but sometimes industrial and anthropogenic wastes from the nearby cities. Some of the major threats posing negative impacts on the richest biodiversity of this deltaic zone are as follows:

> Uncontrolled collection of prawn seedlings: Collection of shrimp/ prawn seeds by the local villagers, for supplying to the commercial prawn culture firms has become an extremely attractive economic activity of common livelihood of Indian Sundarbans people, due to which a large variety of fin-fish and shell-fish juveniles are wasted.

$>$ Irregular fishing: Unscientific fishing practices by the trawlers causes great damage to fishery stock and sea turtle population.

$>$ Lime generation: Exploitation of molluscan shells for lime manufacture prevents calcium recycling into the system and affects the ecological balance.

$>$ Extension of non-forestry land: The increased pressure on land for expansion of activities like aquaculture, prawn farming, drying of seafish, efc. are posing direct threat to the existing Indian Sundarbans mangroves.

$>$ Demand for small timber and fuel wood for local consumption: Illegal cutting of timber and fuel wood from the fringe areas is common. Timber procurement has also caused considerable destruction of mangrove forest.

$>$ Erosion: The process of erosion is a common phenomenon in Indian Sundarbans due to current pattern and building of structures like guide walls, groins, etc. in the upstream region. Absence of protective vegetation cover in many areas of Indian Sundarbans has accelerated the process of erosion.

$>$ Construction of embankment: It affects the drainage systems and cuts off the sweet water flow into adjoining areas, resulting in increased salinity in these areas. Due to the embankments the silt deposition along the inner banks and river beds from the tidal waves have raised the river beds to a higher level than of human settlements. 
$>$ Loss of endangered species: Many species like the tiger, fishing cat, gangetic dolphin, porpoise, adjutant stork, estuarine crocodile and olive ridley turtle have been marked as endangered species due to habitat destruction, increased salinity and illegal trade.

$>$ Man-animal conflict: Straying of tigers into villages causes acufe man-animal conflict, which poses direct threat to conservation efforts.

$>$ Deterioration of water quality: Release of untreated wastes from the nearby city has caused deterioration of water quality in the western sector of Indian Sundarbans.

$>$ Dredging of riverbeds: It is done to improve navigability of large vessels and oil tankers. Such operation directly affects the flora and fauna and also the fishery indirectly.

$>$ Unplanned tourism development: In some regions of the mangrove island tourism have been developed in an unplanned way and so indiscriminate disturbance and environmental pollution are increasing day by day which seem to be an effective cause for destruction of Sundarbans mangrove ecosystem.

\section{Conservation Approaches needed for yielding Sustainable Benefits of Sundarbans}

The threats to Indian Sundarbans are mostly site specific in nature and indirectly related to the nature of resource, their exploitation pattern and socio-economic profile of the area. So there is a need of proper conservation approaches for protecting the richest biodiversity of this region. The greatest enemy of the Sundarbans is the poverty of its people. Deprived of any other means of sustenance, the inhabitants earn their livelihood by felling wood, catching fish-spawn in rivers and hunting, all of which destroy the natural resources and threaten the biodiversity of this area. Public awareness campaigns are urgently needed to inculcate environmental consciousness among people. Alternative means of income should be encouraged, replacing traditional methods that harm the ecosystem.

The Forest Departments and Fisheries Departments of Government of West Bengal and various NGOs have already adopted several strategies to conserve the vibrating mangrove ecosystem of Indian Sundarbans. Some of the important approaches are: 
$>$ Eco-Development and Joint Forest Management support activities

$>$ Afforestation

$>$ Vocational Training for prawn seed collectors

$>$ Encouragement towards alternative livelihood

$>$ Canal excavation

$>$ Oyster culture

$>$ Crab fattening

$>$ Apiculture

$>$ Pisciculture

$>$ Development of Eco-tourism

$>$ Establishment of Interpretation Centres

For keeping the nature in balance and for getting maximum benefit from these mangrove wetlands, more and more planned conservation approaches are required to develop the sustainable awareness in such estuarine lands on an urgent basis, besides the above mentioned protective measures. In this estuarine wetland ecosystem of the Sundarbans, human influence would cause changes raising alarming conditions. So, the main objective should be to convince the local people that they are the proud inhabitants of this World Heritage Site.

\section{Training Activities}

In collaboration with the Forest Department other organizations should come forward to train the local people in alternative means of livelihood like -

a) Potential agriculture techniques and procedures; such as - fodder and forage grass cultivation, medicinal plant gardening and the plantation of the selected fruit trees and timber producing plants, fibre yielding trees which may also help to improve the rural economy. By this artificial afforestation programme and by developing the social forestry, the pressure on the mangrove forest trees may be minimized.

b) Economic and sustainable uses of the natural resources of the Sundarbans and other socio-economic implications may be considered. 


\section{Educational Activities}

To generate mass education about this threatened environment some awareness programmes should be arranged in different localities. By arranging such type of programme, people may be made aware about the -
a) causes of degradation of the mangrove environment with special reference to anthropogenic activities.
b) means and methods of preservation of the endangered or threatened mangrove biota and mangrove ecosystem of Sundarbans.
a) effect of tourism development in the mangroves and recreation should be planned in such manner that the ecology is not destroyed.
b) needs for wildlife development and conservation.

\section{Other Activities}

a) Survey and analysis of eco parameters of this threatened mangrove ecosystem may be done in collaboration with Government departments and various NGOs.

b) Documentation of the significant faunal diversity followed by statistical data analysis of the scientific investigations is essential for keeping in mind the present status of the environment.

\section{Reduction of Man- Animal Conflict}

Straying of tigers from the Reserved Forests into the habitations along the Northern and Western fringes of Sundarban Forest occasionally result into death of cattle/ human beings as well as tiger. Illegal entry of fishermen into core areas as well as entry of honey-collectors into the forest also leads to killing of a number of people by the tigers. An ex-gratia relief of Rs 30,000/-is paid for human casualty.

In order to prevent straying of tiger into villages, Nylon net as well as Goran chita fencing are being erected along the forest-village interface. Tranquilisation and capture of the straying animal and their subsequent release into the forest, is also frequently resorted to. Training of the staff in use of tranquilizer gun, use of capture cage/net, quick response at the time of straying and generating support of the villagers are part of capacity building initiatives to tackle tiger straying. These efforts, coupled with Eco-development activities are paying dividend. Between 1994-95 and $2001-02$, there had been 25 recorded cases of tiger straying, leading to death 
of 10 tigers whereas during 2002-03 to 2005-06, there were 20 cases of tiger straying with only one tiger getting killed, that too for self-defense.

\section{Future of the Sundarban}

Two major factors will determine the future of the Sundarban mangroves and their biological diversity. First, the demand on freshwater resources is bound to grow as the human population in both countries continues to increase, resulting in the restriction of freshwater flows to the monsoon season when extensive floods occur in the eastern parts of India and in Bangladesh. The resultant increase in salinisation and accretion of sediments may alter vegetation composition. Impacts on animal communities may also occur due to both, the direct effects of salinity and indirectly through food chain modifications caused by the alterations in the nature and amount of detritus available in the mangrove ecosystem.

Therefore, it is the human response to the spatial and temporal variability in precipitation, and hence the freshwater availability, which will determine the water availability for sustaining the functions and values of the mangroves. The proposed plan of India for the inter-basin transfer of water through a river-linking program in India has already raised concern for the fate of the Sundarban and its rich biodiversity, as well as for the millions of people dependent upon it (Ahmed et al., 2004).

Secondly, global climate change is expected to increase the average temperature and spatio-temporal variability in precipitation, as well as cause a rise in sea level (Ellison, 1994). The increase in temperature and variability in rainfall will put further pressure on freshwater resources and hence, alter the freshwater inflows to the mangroves. If precipitation declines in the Ganga-Brahmaputra basins it may lead to a further reduction in the availability of freshwater in the deltaic region. Some models of climate change also present an increased frequency of tropical cyclones and storm surges, which may cause further changes in freshwater-seawater interactions and hence affect the mangroves (Ali, 1995, 2003; Ali et al., 1997). Substantial areas of the Sundarban along the coast are expected to be inundated by seawater in this case, and the increased landward salinity intrusion would affect the biotic composition.

Ultimately, the future of the Sundarban mangroves hinges upon the efficiency of managing the limited freshwater resources for meeting both human and environmental needs, coupled with effective adaptive responses to the added threats from climate change. 
The proper activities for conserving the threatened environment of the Sundarbans are perhaps one of the sources to create any sustainable development. It is urgent to educate the rural people about the role of the mangrove ecosystem and ensuring alternative sources of livelihood for them. It is expected that only by developing a sense of local awareness that this threatened environment of Indian Sundarbans mangals be properly preserved.

\section{Literature cited}

- Ahmed, M. Feroze, Q. K. Ahmad and Md. Khalequzzaman, 2004. Regional Cooperation on Transboundary Rivers: Impact of the Indian River Linking Project. Proceedings of an International Conference. Bangladesh Poribesh Andolan and Bangladesh Environment Network, Dhaka, $540 \mathrm{pp}$.

- Ali, Anwar, 1995. Numerical investigation into retardation of flood water out flow through the Meghna river in Bagladesh due to SW monsoon wind. Estuarine Coastal and Shelf Science 41:689-704.

- Ali, Anwar, 2003. Vulnerability of Bangladesh coastal region to climate change with adaptation options. http:// www.survas.mdx.ac.uk/pdfs/ 3anwaral.pdf

- Ali, Anwar, H. Rahman and S. S. H. Chowdhury, 1997. River discharge, storm surges and tidal interactions in the Meghna river mouth in Bangladesh. Mausam 48: 531-540.

- Chakrabarti, Kalyan. 1984. Dyanamics of Flora-Fauna Diversity in the Mangroves of Sundarbans and Laterite Tracts of West Bengal, India - A Bio-Ecological Study. Environment \& Ecology, 7 (3): 220-232

- Chaudhuri, A. B. and A. Choudhury, 1994. Mangroves of the Sundarbans. Volume 1: India., $247 \mathrm{pp}$.

- Das, M. K., 1999. Fish and prawn disease epizoobiotics in aquatic ecosystems around Sundarban - an overview. In: D. N. Guha Bakshi, P. Sanyal and K. R. Naskar (eds.), Sundarbans Mangal. Naya Prokash, Calcutta, pp. 485-492.

- Ellison, J. C., 1994. Climate change and sea level rise impacts on mangrove ecosystems. In: J. Pernetta, R. Leemans, D. Elder and S. Humphrey (eds.), Impacts of Climate Change on Ecosystems and Species: Marine and Coastal Ecosystems. IUCN, Gland, pp. 11-30. 
- Kar, Samit ed. 2005. Sundarbans - Problems and Prospects. acb publication: Kolkata. pp. 86-93, 78-81

- Mitra, Abhijit and Pal, Sudipa. 2002. The Oscillating Mangrove Ecosystem and the Indian Sundarbans. (Baneriee, Shakti Ranjan eds.) World Wide Fund for Nature-India: Kolkata. p.19-25

- Mandal, Aparna. 2004. Sundarbans - An Ecological History. Readers Service Kolkata. p.38-58.

- Mandal, Asim Kumar.2003. The Sundarbans of India-A Development Analysis. INDUS: New Delhi. p.78-91.

- Mitra, Abhilit and Baneriee, Kakoli. 2006. Living Resources of the Sea: Focus Indian Sundarbans. (Banerjee, Shakti Ranjan ed.) World Wide Fund for Nature-India: Kolkata. pp.83-89, 91-105.

- Mitra, Abhijit, Baneriee, Kakoli and Bhattacharyya, D. P. Ecological Profile of Indian Sundarbans: Pelagic Primary Producer Community. (Baneriee, Shakti Ranjan eds.), World Wide Fund for Nature -India: Kolkata. 1: p. $17-26$.

- Mukheriee, Ajit Kumar. 1975. The Sundarban of India and its Biota. J.Bombay Nat. Hist. Soc., 72 (1): p. 1-20

- Mukheriee, A. K., 1975. The Sundarban of India and its biota. Journal of the Bombay Natural History Society 72: 1-20.

- Mukheriee, A.K. 1984. Mangrove Wealth of Indian Sundarbans Utilisation and Conservation, J. Econ. Tax. Bot., 5 (1): p. 227-231

- Nandi, N.C. 1984. Faunal Resources of Sundarbans - its Prespective and Predicaments. Environment \& Ecology, 2: p. 99-102

- Naskar, Kumudranjan, Mandal, Rathindranath. 1999. Ecology and Biodiversity of Indian Mangroves, Daya Publishing House: Delhi. p.188195. 